Check for updates

Cite this: RSC Adv., 2019, 9, 17341

Received 21st March 2019

Accepted 27th May 2019

DOI: $10.1039 / c 9 r a 02204 j$

rsc.li/rsc-advances

\title{
A facile approach to 2-alkoxyindolin-3-one and its application to the synthesis of $N$-benzyl matemone $\uparrow$
}

 \\ 2-Alkoxycarbonylindolin-3-one is synthesized from a methoxyglycine derivative via a 1,2-aza-Brook \\ rearrangement followed by cyclization with bis(trimethylsilyl)aluminum chloride. A short-step \\ synthesis of $\mathrm{N}$-benzyl matemone is successfully carried out using the present indolin-3-one \\ synthesis.
}

\section{Introduction}

Heterocyclic compounds possessing an oxindole ${ }^{1}$ skeleton have received considerable attention due to the widespread existence of naturally occurring bioactive materials containing this particular heterocycle. Among them brominecontaining and/or 2-alkoxy indolin-3-one and indole alkaloids such as matemone $3,{ }^{2}$ cephalinone $4,{ }^{3}$ and bromoaplysinopisin 6 (ref. 4) show intriguing bioactivities. Regarding matemone, it was isolated from the Indian Ocean sponge Iotrochota purpurea and its structure was elucidated in 2000. Matemone shows mild cytotoxicity against three cancer cell lines and marginal antibacterial activity against Staphylococcus aureus. We have been interested in the reactivity of $\alpha$ iminoesters in umpolung reactions, ${ }^{5}$ and a facile indolin-3one synthesis via aza-Brook rearrangement has been developed (Scheme 1). ${ }^{6}$

However, difficulties have been encountered regarding the substituents at the 2-position, i.e., only 2,2-disubstituted derivatives 2 could be synthesized by our previously reported procedure (compound $2, \mathrm{R}=\mathrm{Ar}$ or $\mathrm{CO}_{2} \mathrm{R}^{\prime}$ ).

For the construction of matemone and related structures, a procedure using the aldimine of type $\mathbf{1}(\mathrm{R}=\mathrm{H})$ is needed; in particular, a facile approach to 2-mono-substituted indolin-3one, a key intermediate is needed. We have now found that methoxyglycine derivative $\mathbf{1 1}$ serves as a good precursor to the aldimine 10, and 2-alkoxycarbonylindolin-3-one has been successfully synthesized using this particular imine precursor 11 (Scheme 2).

${ }^{a}$ School of Energy Science and Engineering, Nanjing Tech University, Nanjing 211816, Jiangsu Province, China

${ }^{b}$ Department of Chemistry for Materials, Graduate School of Engineering, Mie University, Tsu, Mie 514-8507, Japan. E-mail: mshimizu@chem.mie-u.ac.jp

$\dagger$ Electronic supplementary information (ESI) available. See DOI: 10.1039/c9ra02204j

\section{Results and discussion}

For the synthesis of this particular aldimine 10, we examined several approaches, such as direct imination of glyoxylate through dehydration and oxidation of glycine derivatives $\mathbf{9}$ $\left(\mathrm{MnO}_{2}, \mathrm{DDQ}\right.$, NBS, etc.). ${ }^{7}$ However, none of the attempted procedures worked, and only complex mixtures were obtained (Scheme 3).

We finally found that the methoxyglycine derivative $\mathbf{1 1}$ could be isolated in good yield and served as a stable imine precursor. ${ }^{8}$ Cyclization reaction of this methoxy amino diester 11 was carried out with (TMS) $)_{2} \mathrm{AlCl}^{9}{ }^{9}$ and the results are summarized in Table 1.

An initial examination using 2.0 equiv. of (TMS $)_{2} \mathrm{AlCl}$ in EtCN as a solvent led to the formation of the desired indolin3 -one 12 in only $15 \%$ yield (entry 1 ). Increasing the amount of (TMS) ${ }_{2} \mathrm{AlCl}$ to 4.0 equiv. improved the yield to $56 \%$ (entry 2 ). However, the use of a large excess of the reagent decreased the yield (entry 3). Use of other solvents such as $\mathrm{CH}_{2} \mathrm{Cl}_{2}, \mathrm{Et}_{2} \mathrm{O}$, and THF was unsuccessful (entries 7, 9 and 10). Regarding the reaction temperature, the treatment of the starting

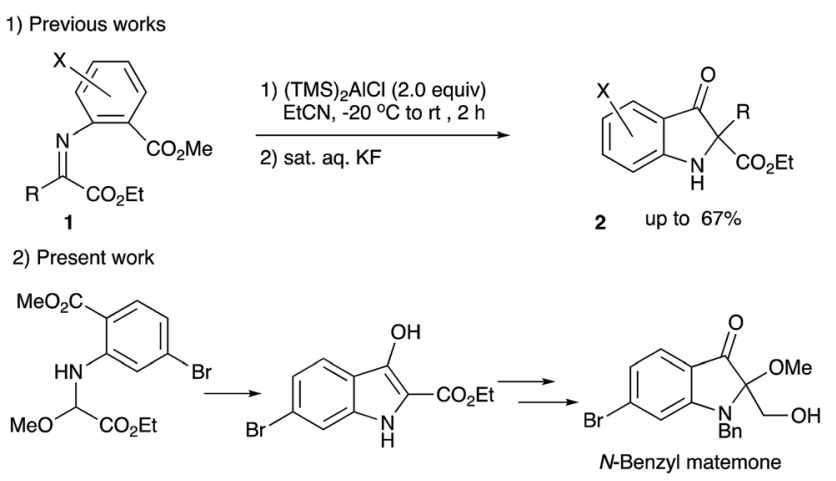

Scheme 1 A new approach to indolin-3-ones and the present $N$ benzyl matemone synthesis. 

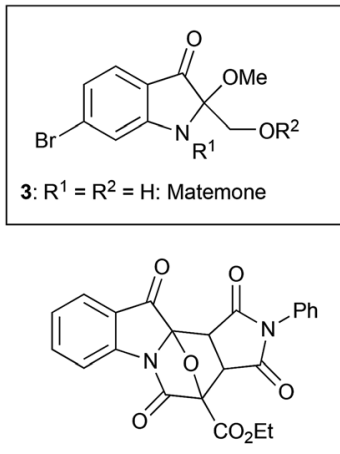

5: Modulator B

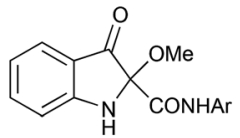

4: $\mathrm{Ar}=2-\mathrm{MeO}_{2} \mathrm{CC}_{6} \mathrm{H}_{4}:$ Cephalinone $\mathrm{B}$

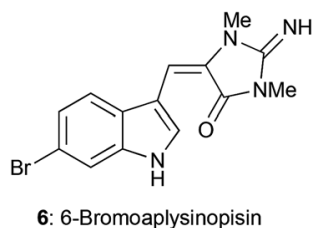

Scheme 2 Bioactive compounds possessing 2-alkoxyindolin-3-one and a related structure.<smiles>COc1ccc(Br)cc1N</smiles>

$\mathrm{MeO}_{2} \mathrm{C}$<smiles>CCOC(=O)c1ccc(Br)cc1NC(C)OCC</smiles>
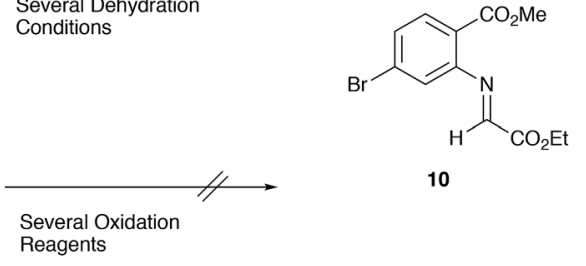

10

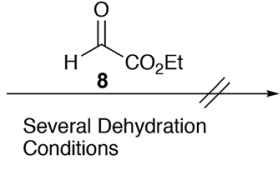

Reagents<smiles>CC(=O)c1ccc(Br)cc1N</smiles>

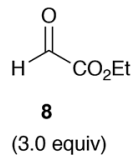



$1187 \%$
Scheme 3 Attempted synthesis and a precursor 11 to the aldimine 10 material 11 with (TMS) ${ }_{2} \mathrm{AlCl}$ at $-78{ }^{\circ} \mathrm{C}$, followed by warming the whole mixture to room temperature recorded the best result (entry 2). The following Scheme 4 shows a possible reaction pathway.

First, the aldimine $\mathbf{1 0}$ is formed in situ by the treatment of the methoxyglycine derivative $\mathbf{1 1}$ with bis(trimethylsilyl) aluminum chloride. The formation of the imine $\mathbf{1 0}$ was detected by a direct injection EI-MS $(\mathrm{m} / \mathrm{z} 313)$. This imine 10 would be attacked by the second equivalent of bis(trimethylsilyl)aluminum chloride to form the aluminum enolate 13 via an aza-Brook rearrangement. ${ }^{10}$ A subsequent Dieckmann cyclization followed by hydrolysis gives the indolin-3-one 12 (Scheme 5).

For the synthesis of matemone 3 , the introduction of the methoxy group at the C-2 position is needed. After several attempts using a series of oxidation reagents, we found that the oxidation of the silyl enol ether 15 with NBS in methanol gave satisfactory results. ${ }^{11,12}$ However, selective reduction at the ester moiety was not successful. ${ }^{13}$ Bis-reduction at the ketone and the ester moieties followed by oxidation at the benzylic alcohol was also failed to give only complex mixtures. We then changed the order of the functional group transformations, i.e., reduction of the ester moiety, followed by the introduction of the methoxy group. This procedure worked well to give $N$-benzyl matemone 17 in high yield (Scheme 6).

This intriguing oxidation into the methoxy derivative $\mathbf{1 7}$ is explicable in terms of the formation of the iminium species 19, which is attacked by methanol (Scheme 7).

We next attempted removal of the benzyl group under a series of conditions (RSH/base, TMSI, Ca or Na/liq. $\mathrm{NH}_{3}$, $\mathrm{H}_{2}$ /Pd or Pt, etc.). Although a small amount of matemone was detected by the mass spectra of the crude reaction mixtures, attempted isolation by silica gel chromatography was not

Table 1 Preparation of indolin-2-one 12

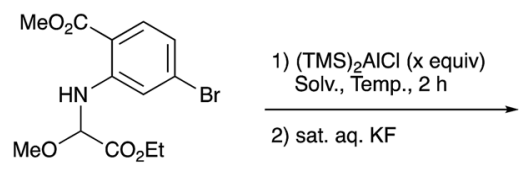<smiles>CCOC(=O)c1[nH]c2cc(Br)ccc2c1O</smiles>

12

\begin{tabular}{|c|c|c|c|c|}
\hline Entry & Temperature & (TMS) ${ }_{2} \mathrm{AlCl}$ (equiv.) & Solvent & Yield of $12^{a}(\%)$ \\
\hline 1 & $-78{ }^{\circ} \mathrm{C}$ to $\mathrm{rt}$ & 2.0 & EtCN & 15 \\
\hline 2 & $-78^{\circ} \mathrm{C}$ to $\mathrm{rt}$ & 4.0 & EtCN & 56 \\
\hline 3 & $-78^{\circ} \mathrm{C}$ to $\mathrm{rt}$ & 6.0 & EtCN & 38 \\
\hline 4 & $-40{ }^{\circ} \mathrm{C}$ to $\mathrm{rt}$ & 4.0 & EtCN & 37 \\
\hline 5 & -78 to $0{ }^{\circ} \mathrm{C}$ & 4.0 & EtCN & 36 \\
\hline 6 & -78 to $50^{\circ} \mathrm{C}$ & 4.0 & EtCN & 46 \\
\hline 7 & $-78^{\circ} \mathrm{C}$ to $\mathrm{rt}$ & 4.0 & $\mathrm{CH}_{2} \mathrm{Cl}_{2}$ & 6 \\
\hline 8 & $-78^{\circ} \mathrm{C}$ to $\mathrm{rt}$ & 4.0 & $\mathrm{EtCN} / \mathrm{CH}_{2} \mathrm{Cl}_{2}(1: 1)$ & 50 \\
\hline 9 & $-78^{\circ} \mathrm{C}$ to $\mathrm{rt}$ & 4.0 & $\mathrm{Et}_{2} \mathrm{O}$ & 26 \\
\hline 10 & $-78^{\circ} \mathrm{C}$ to $\mathrm{rt}$ & 4.0 & THF & 38 \\
\hline
\end{tabular}

${ }^{a}$ Isolated yield. 

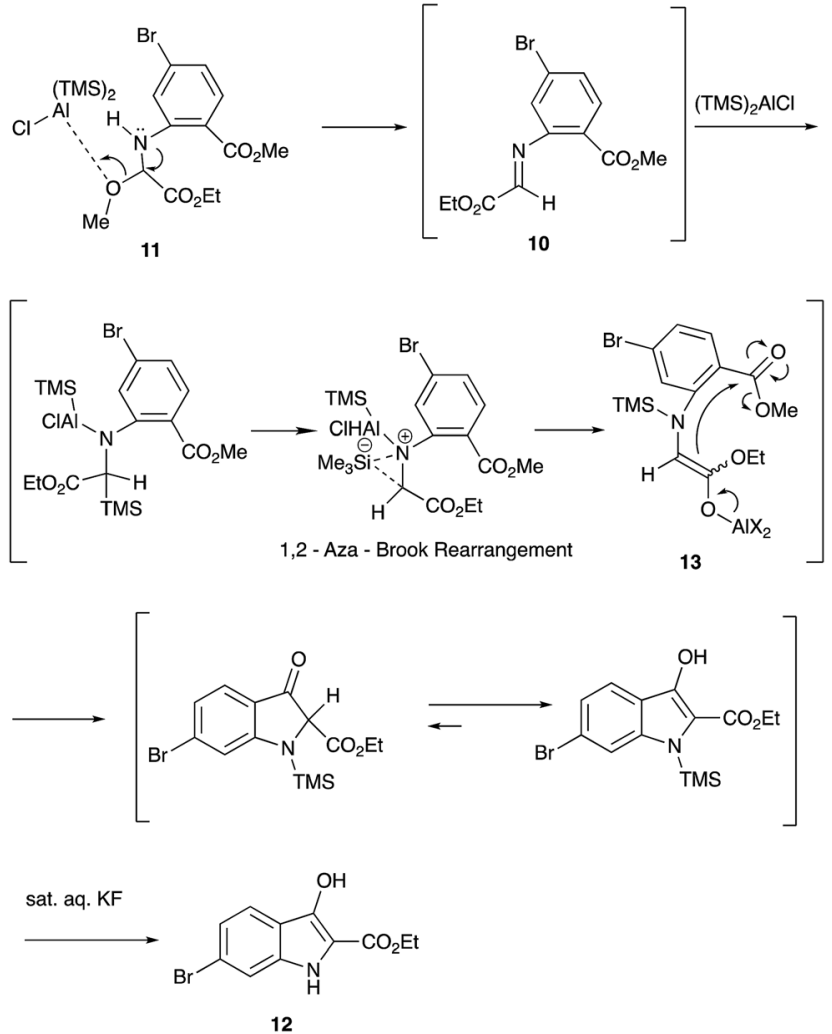

Scheme 4 A proposed reaction mechanism of the indolin-3-one 12 synthesis.<smiles>CCOC(=O)c1[nH]c2cc(Br)ccc2c1O</smiles>

12 $\mathrm{K}_{2} \mathrm{CO}_{3}$ (1.2 equiv)

$\mathrm{MeOH}$,refl, $16 \mathrm{~h}$<smiles>CCOC1(OC)Nc2cc(Br)ccc2C1=O</smiles>

$1697 \%$
$\mathrm{BnBr}(1.2$ equiv)



$1494 \%$

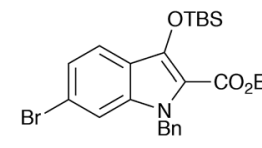

$1594 \%$
Scheme 5 Introduction of 2-methoxy group.

successful. We also attempted the isolation as an acetate form by treatment of the whole reaction mixtures with an excess $\mathrm{AcCl} / \mathrm{base}$. However, the acetate was not isolated in sufficient quantity. Studies indicated that unprotected matemone was unstable due to a solvent-induced polymerization process. $^{2}$ Therefore, matemone was immediately converted to the stable acetate derivative $3\left(\mathrm{R}^{2}=\mathrm{Ac}\right)$, and detailed spectroscopic analyses were carried out with the acetate derivative. We found that $N$-protected matemone 18 was also reasonably stable and would be subject to further functional group interconversions. ${ }^{\mathbf{1 4}}$
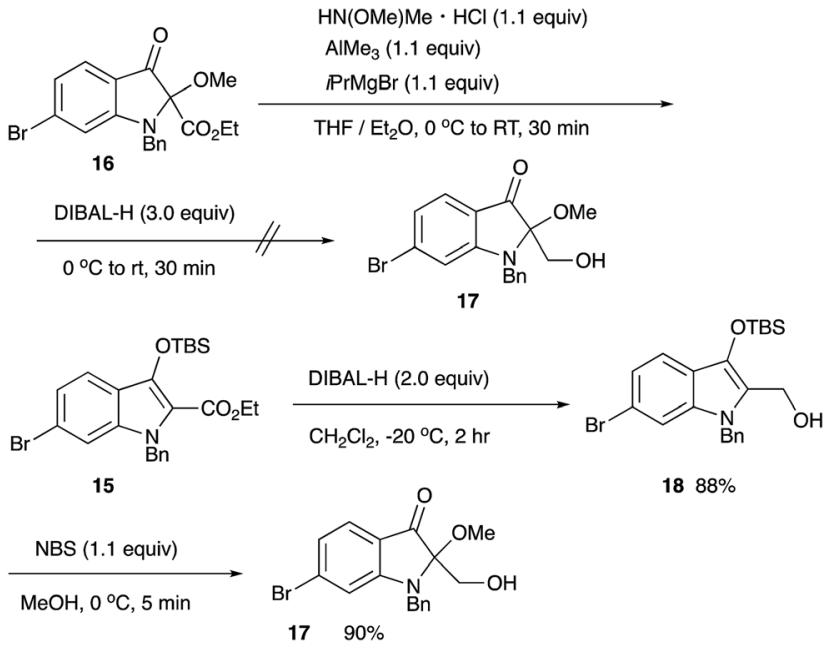

Scheme 6 Synthesis of $N$-benzyl matemone.

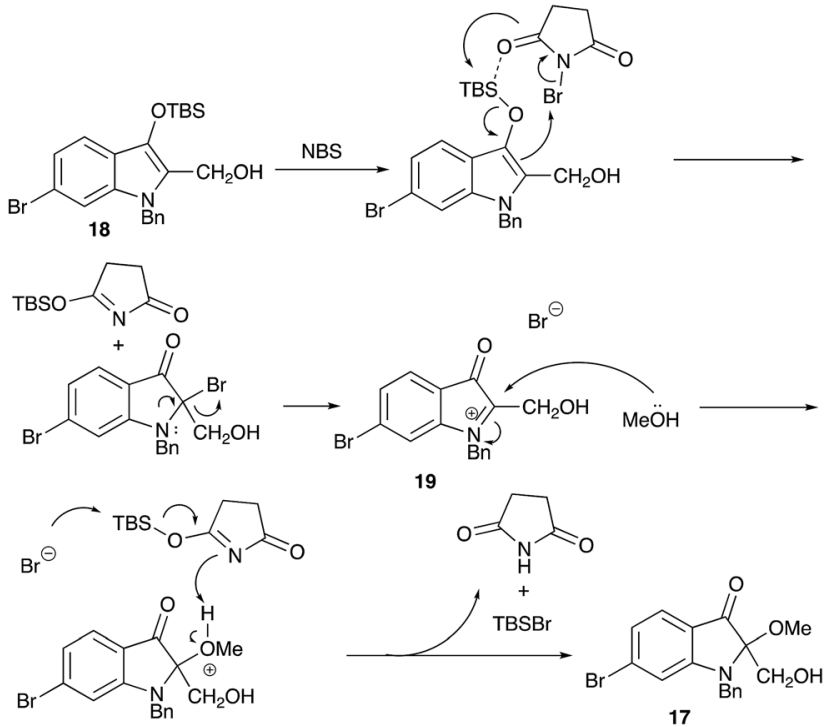

Scheme 7 A proposed pathway for the introduction of a methoxy group.

\section{Conclusions}

We have found that the methoxyglycine derivative $\mathbf{1 1}$ is a good precursor to the aldimine $\mathbf{1 0}$ derived from glyoxylate, and the subsequent treatment of this particular methoxyglycine 11 with bis(trimethylsilyl)aluminum chloride provides 2alkoxycarbonylindolin-3-ones. Further oxidation of the silyl enol ether prepared from the 2-alkoxycarbonylindolin-3-one undergoes a facile oxidation reaction with NBS in methanol to give the 2-methoxy derivatives in high yields. This procedure has proved to be effective for the synthesis of $N$-benzyl matemone as a reasonably stable derivative. Although we have not examined the bioactivity of the $N$-benzyl matemone 17 yet, we will submit it and other derivatives to bioassay in due course. 


\section{Experimental}

\section{General aspects}

Infrared spectra were determined on a JASCO FT/IR-460 plus spectrometer. ${ }^{1} \mathrm{H}$ NMR and ${ }^{13} \mathrm{C}$ NMR spectra were recorded with a JEOL ECX-400P, or a JEOL A-500 spectrometer using tetramethylsilane as an internal standard. Mass spectra were recorded on a JEOL MS-700D spectrometer. Propionitrile (EtCN) and acetonitrile (MeCN) were distilled from phosphorus pentoxide and then from calcium hydride and stored over Molecular Sieves 4 A. Dichloromethane $\left(\mathrm{CH}_{2} \mathrm{Cl}_{2}\right)$ was distilled from calcium hydride and stored over Molecular Sieves $4 \AA$ A. Toluene was dried over calcium chloride, distilled, and stored over Molecular Sieves 4 A. Diethyl ether $\left(\mathrm{Et}_{2} \mathrm{O}\right)$ and tetrahydrofuran (THF) were distilled from benzophenone ketyl immediately before use or purified by Glass Contour Organic Solvent Purification System of Nikko Hansen \& Co., Ltd. $\mathrm{MeOH}$ was heated at reflux over magnesium for $5 \mathrm{~h}$, distilled, and stored over Molecular Sieves $3 \AA$ A. Purification of products was performed by column chromatography on silica gel (Kanto Silica Gel 60N) and/or preparative TLC on silica gel (Merck Kiesel Gel GF254 or Wako Gel B-5F).

\section{Methyl 4-bromo-2-[(2-ethoxy-1-methoxy-2-oxoethyl)amino]- benzoate (11)}

In a $30 \mathrm{~mL}$ two-necked round-bottomed flask equipped with a magnetic stirring bar, a rubber septum and an argon balloon were placed methyl 2-amino-4-bromobenzoate (460.0 mg, 2.00 mmol) prepared according to the reported procedures, ${ }^{15}$ ethyl glyoxylate $(1.23 \mathrm{~mL}, 6.00 \mathrm{mmol}, 50 \%$ in toluene), and methanol $(10.0 \mathrm{~mL})$, respectively. The mixture was stirred at reflux for $16 \mathrm{~h}$. After cooling to room temperature, the mixture was concentrated in vacuo to give a crude oil, which was purified by silica gel chromatography (nhexane : ethyl acetate $=6: 1$ ) to give the title compound $\mathbf{1 1}(604.6 \mathrm{mg}, 87 \%)$ as white crystals.

Yield $87 \%$ (604.6 mg); white crystals; $\mathrm{mp} 86-88{ }^{\circ} \mathrm{C} ; R_{\mathrm{f}}=0.50$ ( $n$ hexane : ethyl acetate $=4: 1) ;{ }^{1} \mathrm{H} \mathrm{NMR}\left(400 \mathrm{MHz}, \mathrm{CDCl}_{3}\right.$ ) $\delta 1.36(\mathrm{t}, J=7.3 \mathrm{~Hz}, 3 \mathrm{H}), 3.30(\mathrm{~s}, 3 \mathrm{H}), 3.89(\mathrm{~s}, 3 \mathrm{H}), 4.34(\mathrm{q}, J=$ $7.3 \mathrm{~Hz}, 2 \mathrm{H}), 5.26(\mathrm{~d}, J=6.4,1 \mathrm{H}), 6.88-6.91(\mathrm{~m}, 1 \mathrm{H}), 7.13(\mathrm{~d}, J=$ $1.8 \mathrm{~Hz}, 1 \mathrm{H}), 7.79(\mathrm{~d}, J=8.7 \mathrm{~Hz}, 1 \mathrm{H}), 8.98(\mathrm{~d}, J=6.4 \mathrm{~Hz}, 1 \mathrm{H}) ;{ }^{13} \mathrm{C}$ NMR (100 MHz, $\left.\mathrm{CDCl}_{3}\right) \delta 14.1,51.6,51.9,62.2,81.4,110.9$, 116.1, 120.7, 129.5, 132.7, 148.6, 167.9, 168.0; IR (neat) 3329, 2952, 1743, 1693, 1571, 1505, 1240, 1095, 1064, $769 \mathrm{~cm}^{-1}$; HRMS (EI) calcd for $\mathrm{C}_{13} \mathrm{H}_{16} \mathrm{BrNO}_{5}(\mathrm{M})^{+} 345.0212$ found 345.0196.

\section{General procedure: synthesis of ethyl 6-bromo-3-hydroxy-1H- indole-2-carboxylate (12) (Table 1)}

Under an argon atmosphere, a solution of methyl 4-bromo-2-[(2ethoxy-1-methoxy-2-oxoethyl)amino]-benzoate 11 (100.0 mg, $0.29 \mathrm{mmol})$ in EtCN $(30.0 \mathrm{~mL})$ was placed at $-78^{\circ} \mathrm{C}$ and to it was added a propionitrile solution $(10 \mathrm{~mL})$ of (TMS $)_{2} \mathrm{AlCl}$, which was prepared by mixing aluminum chloride $(52.0 \mathrm{mg}, 0.39 \mathrm{mmol})$ and $(\mathrm{TMS})_{3} \mathrm{Al} \cdot \mathrm{Et}_{2} \mathrm{O}\left(0.62 \mathrm{~mL}, 0.77 \mathrm{mmol}, 1.25 \mathrm{M}\right.$ in $\left.\mathrm{Et}_{2} \mathrm{O}\right)$ at room temperature in another flask. After the mixture was stirred for 2 hours at room temperature, to it was added saturated aqueous potassium fluoride followed by a saturated aqueous
Rochelle's salt to quench the reaction. The whole mixture was extracted with ethyl acetate $(10 \mathrm{~mL} \times 3)$. The combined organic phases were washed with brine, dried over $\mathrm{Na}_{2} \mathrm{SO}_{4}$, and concentrated in vacuo to give a crude product. Purification by silica gel column chromatography ( $n$ hexane : ethyl acetate $=$ $4: 1$ as an eluent) gave ethyl 6-bromo-3-hydroxy- $1 H$-indole-2carboxylate $12(44.8 \mathrm{mg}, 56 \%)$ as yellow crystals.

Yield 56\% (44.8 mg); mp 167-169 ${ }^{\circ} \mathrm{C}$; yellow crystals; $R_{\mathrm{f}}=$ 0.32 (nhexane : ethyl acetate $=4: 1) ;{ }^{1} \mathrm{H}$ NMR $\left(400 \mathrm{MHz}, \mathrm{CDCl}_{3}\right)$ $\delta 1.41(\mathrm{t}, J=6.9 \mathrm{~Hz}, 3 \mathrm{H}), 4.39(\mathrm{q}, J=6.9 \mathrm{~Hz}, 2 \mathrm{H}), 7.04-7.06(\mathrm{~m}$, 1H), 7.48-7.49 (m, 1H), 7.58-7.60 (m, 1H), 8.79 (s, 1H), 10.70 (s, $1 \mathrm{H}) ;{ }^{13} \mathrm{C} \mathrm{NMR}\left(100 \mathrm{MHz}, \mathrm{CDCl}_{3}\right) \delta 13.2,58.7,108.1,113.6,115.5$, 118.0, 119.9, 120.3, 134.2, 142.8, 160.9; IR (neat) 3341, 1672, 1608, 1583, 1308, 1240, 1141, 1104, 1018, $770 \mathrm{~cm}^{-1}$; HRMS (EI) calcd for $\mathrm{C}_{11} \mathrm{H}_{10} \mathrm{BrNO}_{3}(\mathrm{M})^{+} 282.9844$ found 282.9842 .

\section{Ethyl 6-bromo-3-[(tert-butyldimethylsilyl)oxy]-1H-indole-2- carboxylate (14)}

In a $50 \mathrm{~mL}$ two-necked round-bottomed flask equipped with a magnetic stirring bar, a rubber septum and an argon balloon was placed ethyl 6-bromo-3-hydroxy-1 $H$-indole-2-carboxylate (125.4 mg, $0.44 \mathrm{mmol}$ ), DMAP (0.09 mmol, $10.8 \mathrm{mg}$ ), triethylamine $(0.12 \mathrm{~mL}, 0.88 \mathrm{mmol})$ and $\mathrm{CH}_{2} \mathrm{Cl}_{2}(10 \mathrm{~mL})$, and to it was added a solution of TBDMSCl $(0.88 \mathrm{mmol}, 132.6 \mathrm{mg})$ in $\mathrm{CH}_{2} \mathrm{Cl}_{2}$ $(4 \mathrm{~mL})$. After the mixture was stirred for $16 \mathrm{~h}$ at room temperature, it was concentrated in vacuo to give a crude oil, which was purified by silica gel column chromatography (nhexane : ethyl acetate $=6: 1)$ to give the title compound $14(165.0 \mathrm{mg}, 94 \%)$ as white crystals.

Yield 94\% (165.0 mg); white crystals; mp $135-136{ }^{\circ} \mathrm{C} ; R_{\mathrm{f}}=$ 0.54 (nhexane : ethyl acetate $=4: 1) ;{ }^{1} \mathrm{H} \mathrm{NMR}\left(400 \mathrm{MHz}, \mathrm{CDCl}_{3}\right)$ $\delta 0.21(\mathrm{~s}, 6 \mathrm{H}), 1.09(\mathrm{~s}, 9 \mathrm{H}), 1.43(\mathrm{t}, J=6.9,3 \mathrm{H}), 4.44(\mathrm{q}, J=7.3$, 2H), 7.19-7.17 (m, 1H), 7.47-7.49 (m, 2H), $8.65(\mathrm{~s}, 1 \mathrm{H}) ;{ }^{13} \mathrm{C}$ NMR $\left(100 \mathrm{MHz}, \mathrm{CDCl}_{3}\right) \delta-4.2,14.7,18.3,25.7,60.7,114.4,114.7$, 120.0, 120.6, 121.5, 123.0, 133.8, 139.7, 161.7; IR (neat) 3313, 2952, 1675, 1568, 1472, 1316, 1240, 1145, 851, $783 \mathrm{~cm}^{-1}$; HRMS (EI) calcd for $\mathrm{C}_{17} \mathrm{H}_{24} \mathrm{BrNO}_{3} \mathrm{Si}(\mathrm{M})^{+} 397.0709$ found 397.0707 .

\section{Ethyl 1-benzyl-6-bromo-3-[(tert-butyldimethylsilyl)oxy $]-1 H$-indole- 2-carboxylate (15)}

In a $30 \mathrm{~mL}$ two-necked round-bottomed flask equipped with a magnetic stirring bar, a rubber septum and an argon balloon was placed ethyl 6-bromo-3-[(tert-butyldimethylsilyl)oxy]-1 $\mathrm{H}^{-}$ indole-2-carboxylate (37.0 mg, $0.09 \mathrm{mmol}), \mathrm{K}_{2} \mathrm{CO}_{3}(15.2 \mathrm{mg}, 0.11$ $\mathrm{mmol})$, benzyl bromide $(0.01 \mathrm{~mL})$ and $\mathrm{MeCN}(15 \mathrm{~mL})$, and to it was added a solution of TBDMSCl $(132.6 \mathrm{mg}, 0.88 \mathrm{mmol})$ in MeCN (15 mL, $0.11 \mathrm{mmol}$ ). After the mixture was stirred for $16 \mathrm{~h}$ at reflux, it was filtered through a plug of cotton and concentrated in vacuo to give a crude oil, which was purified on silica gel TLC (nhexane : ethyl acetate $=5: 1$ ) to give the title compound 15 (165.0 mg, 94\%) as a colourless oil.

Yield 94\% (41.1 mg); colourless oil; $R_{\mathrm{f}}=0.68$ ( $n$ hexane : ethyl acetate $=4: 1) ;{ }^{1} \mathrm{H}$ NMR $\left(400 \mathrm{MHz}, \mathrm{CDCl}_{3}\right) \delta 0.18(\mathrm{~s}, 6 \mathrm{H}), 1.08(\mathrm{~s}$, $9 \mathrm{H}), 1.28(\mathrm{t}, J=7.1,3 \mathrm{H}), 4.31(\mathrm{q}, J=7.3,2 \mathrm{H}), 5.65(\mathrm{~s}, 2 \mathrm{H}), 6.95-$ $6.97(\mathrm{~m}, 2 \mathrm{H}), 7.16-7.25(\mathrm{~m}, 4 \mathrm{H}), 7.43-7.44(\mathrm{~m}, 1 \mathrm{H}), 7.49-7.51$ $(\mathrm{m}, 1 \mathrm{H}) ;{ }^{13} \mathrm{C} \mathrm{NMR}\left(100 \mathrm{MHz}, \mathrm{CDCl}_{3}\right) \delta-4.2,14.5,18.4,25.8$, 
48.1, 60.3, 133.3, 116.0, 119.5, 120.1, 121.7, 123.1, 126.0, 127.1, 128.6, 137.4, 138.1, 141.1, 161.6; IR (neat) 2930, 2857, 1698, 1532, 1437, 1329, 1257, 1119, 830, $781 \mathrm{~cm}^{-1}$; HRMS (EI) calcd for $\mathrm{C}_{24} \mathrm{H}_{30} \mathrm{BrNO}_{3} \mathrm{Si}(\mathrm{M})^{+} 487.1178$ found 487.1163 .

\section{Ethyl 1-benzyl-6-bromo-2-methoxy-3-oxoindoline-2-carboxylate (16)}

In a $30 \mathrm{~mL}$ two-necked round-bottomed flask equipped with a magnetic stirring bar, a rubber septum and an argon balloon was placed NBS (59.1 mg, $0.33 \mathrm{mmol})$ and $\mathrm{MeOH}(6.0 \mathrm{~mL})$, and to it was added a solution of ethyl 1-benzyl-6-bromo-3-[(tertbutyldimethylsilyl)oxy]-1H-indole-2-carboxylate $(59.1 \mathrm{mg}, 0.30$ $\mathrm{mmol})$ in $\mathrm{MeOH}(4 \mathrm{~mL})$ at $0{ }^{\circ} \mathrm{C}$. After the mixture was stirred for $15 \mathrm{~min}$ at $0{ }^{\circ} \mathrm{C}$, to it was added saturated aqueous $\mathrm{K}_{2} \mathrm{CO}_{3}$ to quench the reaction. The whole mixture was extracted with ethyl acetate $(50 \mathrm{~mL} \times 3)$. The combined organic phases were washed with brine, dried over $\mathrm{Na}_{2} \mathrm{SO}_{4}$, and concentrated in vacuo to give a crude product, which was purified by silica gel column chromatography ( $n$ hexane : ethyl acetate $=4: 1$ ) to give the title compound $16(117.6 \mathrm{mg}, 97 \%)$ as a yellow oil.

Yield 97\% (117.6 mg); yellow oil; $R_{\mathrm{f}}=0.42$ ( $n$ hexane : ethyl acetate $=4: 1) ;{ }^{1} \mathrm{H}$ NMR $\left(400 \mathrm{MHz}, \mathrm{CDCl}_{3}\right) \delta 1.09-1.13(\mathrm{~m}, 3 \mathrm{H})$, 3.27 (s, 3H), 3.96-4.10 (m, 2H), 4.47-4.60 (m, 2H), 6.90-7.05 (m, 2H), 7.29-7.37 (m, 5H), 7.44-7.48 (m, 1H); ${ }^{13} \mathrm{C}$ NMR (100 MHz, $\left.\mathrm{CDCl}_{3}\right) \delta 13.8,46.6,52.1,32.5,112.7,118.0,122.7,126.0,127.1$, $127.7,128.8,134.2,135.9,161.4,165.1,193.5$; IR (neat) 2930, 1721, 1605, 1465, 1311, 1260, 1148, 1098, 906, $699 \mathrm{~cm}^{-1}$; HRMS (EI) calcd for $\mathrm{C}_{17} \mathrm{H}_{16} \mathrm{BrNO}_{3}(\mathrm{M})^{+} 403.0419$ found 403.0414 .

\section{1-Benzyl-6-bromo-3-[(tert-butyldimethylsilyl)oxy-1H-indol-2-yl] methanol (18)}

In a $30 \mathrm{~mL}$ two-necked round-bottomed flask equipped with a magnetic stirring bar, a rubber septum and an argon balloon was placed a solution of ethyl 1-benzyl-6-bromo-3-[(tert-butyldimethylsilyl)oxy]-1 $H$-indole-2-carboxylate $(23.0 \mathrm{mg}, 0.05 \mathrm{mmol})$ in $\mathrm{CH}_{2} \mathrm{Cl}_{2}(5.0 \mathrm{~mL})$, and to it was added dropwise DIBAL-H $(0.09 \mathrm{~mL}$, $0.09 \mathrm{mmol}, 10 \%$ in $n$-hexane) at $-20{ }^{\circ} \mathrm{C}$. After the mixture was stirred for $30 \mathrm{~min}$ at $0{ }^{\circ} \mathrm{C}$, to it was added saturated aqueous Rochelle's salt to quench the reaction. The whole mixture was filtered through a Celite pad, and was extracted with $\mathrm{CH}_{2} \mathrm{Cl}_{2}(10 \mathrm{~mL}$ $\times 3$ ). The combined organic phases were dried over $\mathrm{Na}_{2} \mathrm{SO}_{4}$, and concentrated in vacuo to give a crude product, which was purified on silica gel TLC ( $n$ hexane : ethyl acetate $=4: 1$ ) to give the title compound $18(19.6 \mathrm{mg}, 88 \%)$ as a yellow green oil.

Yield $88 \%$ (19.6 mg); yellow green oil; $R_{\mathrm{f}}=0.31(n$ hexane : ethyl acetate $=4: 1) ;{ }^{1} \mathrm{H}$ NMR $\left(400 \mathrm{MHz} \mathrm{CDCl}_{3}\right) \delta 0.18(\mathrm{~s}$, $6 \mathrm{H}), 1.08$ (s, 9H), 4.65 (d, $J=5.5 \mathrm{~Hz}, 2 \mathrm{H}), 5.38$ (s, 2H), 6.92-6.94 $(\mathrm{m}, 2 \mathrm{H}), 7.14-7.42(\mathrm{~m}, 6 \mathrm{H}) ;{ }^{13} \mathrm{C} \mathrm{NMR}\left(100 \mathrm{MHz}, \mathrm{CDCl}_{3}\right) \delta-4.4$, 18.2 , 25.8, 46.8, 53.5, 112.4, 116.4, 119.8, 120.1, 122.2, 125.0, $125.7,127.4,128.8,132.6,135.3,137.8$; IR (neat) 3413, 2931, 2858, 1584, 1468, 1364, 1253, 1189, 1008, 829, $781 \mathrm{~cm}^{-1}$; HRMS (EI) calcd for $\mathrm{C}_{22} \mathrm{H}_{28} \mathrm{BrNO}_{2} \mathrm{Si}(\mathrm{M})^{+} 445.1073$ found 445.1073 .

\section{1-Benzyl-6-bromo-2-(hydroxymethyl)-2-methoxyindolin-3-one (17)}

In a $30 \mathrm{~mL}$ two-necked round-bottomed flask equipped with a magnetic stirring bar, a rubber septum and an argon balloon was placed NBS (89.4 mg, $0.50 \mathrm{mmol})$ and $\mathrm{MeOH}(25.0 \mathrm{~mL})$, and to it was added a solution of 1-benzyl-6-bromo-3-[(tert-butyldimethylsilyl)oxy-1 $H$-indol-2-yl]methanol $(203.8 \mathrm{mg}, 0.46 \mathrm{mmol}$ ) in $\mathrm{MeOH}(4 \mathrm{~mL})$ at $0{ }^{\circ} \mathrm{C}$. After the mixture was stirred for $5 \mathrm{~min}$ at $0{ }^{\circ} \mathrm{C}$, to it was added saturated aqueous $\mathrm{K}_{2} \mathrm{CO}_{3}$ to quench the reaction. The whole mixture was extracted with ethyl acetate $(50 \mathrm{~mL} \times 3)$. The combined organic phases were dried over $\mathrm{Na}_{2} \mathrm{SO}_{4}$, and concentrated in vacuo to give a crude product, which was purified on silica gel TLC ( $n$ hexane : ethyl acetate $=$ $3: 1)$ to give the title compound 17 (150.4 mg, 90\%) as a yellow green oil.

Yield 90\% (150.4 mg); $R_{\mathrm{f}}=0.19$ ( $n$ hexane : ethyl acetate $=$ $4: 1) ;{ }^{1} \mathrm{H}$ NMR (400 MHz, $\left.\mathrm{CDCl}_{3}\right) \delta 3.12(\mathrm{~s}, 3 \mathrm{H}), 3.65(\mathrm{~d}, J=$ $0.0 \mathrm{~Hz}, 1 \mathrm{H}), 3.85-3.91(\mathrm{~m}, 1 \mathrm{H}), 4.59$ (s, 2H), 6.90-6.96 (m, 2H), 7.36-7.40 (m, 5H), 7.42-7.44 (m, $1 \mathrm{H}) ;{ }^{13} \mathrm{C}$ NMR $(100 \mathrm{MHz}$, $\left.\mathrm{CDCl}_{3}\right) \delta 45.2,52.0,63.9,112.0,114.5,121.9,122.7,125.5,126.7$, 127.8, 129.4, 149.8, 213.3; IR (neat) 3462, 2929, 1716, 1606, 1472, 1312, 1092, 1053, 937, $755 \mathrm{~cm}^{-1}$; HRMS (EI) calcd for $\mathrm{C}_{17} \mathrm{H}_{16} \mathrm{BrNO}_{3}(\mathrm{M})^{+} 361.0314$ found 361.0297 .

\section{Conflicts of interest}

There are no conflicts to declare.

\section{Acknowledgements}

This work was supported by Grants-in-Aid for Scientific Research (B) and on Innovative Areas "Organic Synthesis Based on Reaction Integration. Development of New Methods and Creation of New Substances" from JSPS and MEXT.

\section{Notes and references}

1 (a) T. Kawasaki, A. Ogawa, Y. Takashima and M. Sakamoto, Tetrahedron Lett., 2003, 44, 1591; (b) P. N. Wyrembak and A. D. Hamilton, J. Am. Chem. Soc., 2009, 131, 4566; (c) K. Okuma, N. Matsunaga, N. Nagahora, K. Shioji and Y. Yokomori, Chem. Commun., 2010, 5822; (d) Y. Sun and R. Fan, Chem. Commun., 2010, 6834; (e) W. Sun, L. Hong and R. Wang, Chem.-Eur. J., 2011, 17, 6030; (f) A. Wetzel and F. Gagosz, Angew. Chem., Int. Ed., 2011, 50, 7354.

2 (a) I. Carletti, B. Banaigs and P. Amade, J. Nat. Prod., 2000, 63, 981; (b) S.-S. Wen, Z.-F. Zhou, J.-A. Xiao, J. Li, H. Xiang and H. Yang, New J. Chem., 2017, 41, 11503; (c) For a review see, G. W. Gribble in Progress in Heterocyclic Chemistry, ed by G. W. Gribble and J. A. Joule, Pergamon, Kidlington, vol. 15, 2003, pp. 58-74.

3 (a) P. S. Baran and E. J. Corey, J. Am. Chem. Soc., 2002, 124, 7904; (b) P.-L. Wu, Y.-L. Hsu and C.-W. Jao, J. Nat. Prod., 2006, 69, 1467; (c) L. A. Adams, M. W. N. Valente and R. M. Williams, Tetrahedron, 2006, 62, 5195; (d) D. D. O'Rell, F. G. H. Lee and V. Boekelheide, J. Am. Chem. Soc., 1972, 94, 3205; (e) S. Tsukamoto, H. Umaoka, K. Yoshikawa, T. Ikeda and H. Hirota, J. Nat. Prod., 2010, 73, 1438; ( $f$ ) A. Karadeolian and M. A. Kerr, Angew. Chem., Int. Ed., 2010, 49, 1133; $(g)$ A. Karadeolian and M. A. Kerr, J. Org. Chem., 2010, 75, 6830. 
4 P. H. B. França, D. P. Barbosa, D. L. da Silva, Ê. A. N. Ribeiro, A. E. G. Santana, B. V. O. Santos, J. M. Barbosa-Filho, J. S. S. Quintans, R. S. S. Barreto, L. J. Quintans-Júnior and J. X. de Araújo-Júnior, BioMed Res. Int., 2014, 1.

5 For $N$-alkylation to $\alpha$-imino esters in our laboratory, see, $(a)$ M. Shimizu and Y. Niwa, Tetrahedron Lett., 2001, 42, 2829; (b) Y. Niwa, K. Takayama and M. Shimizu, Tetrahedron Lett., 2001, 42, 5473; (c) Y. Niwa, K. Takayama and M. Shimizu, Bull. Chem. Soc. Jpn., 2002, 75, 1819; (d) Y. Niwa and M. Shimizu, J. Am. Chem. Soc., 2003, 125, 3720; (e) M. Shimizu, H. Itou and M. Miura, J. Am. Chem. Soc., 2005, 127, 3296; (f) M. Shimizu, Pure Appl. Chem., 2006, 78, 1867; $(g)$ M. Shimizu, I. Hachiya and I. Mizota, Chem. Commun., 2009, 874; (h) I. Mizota, K. Tanaka and M. Shimizu, Tetrahedron Lett., 2012, 53, 1847; (i) T. Nishi, I. Mizota and M. Shimizu, Pure Appl. Chem., 2012, 84, 2609; (j) S. Hata, T. Maeda and M. Shimizu, Bull. Chem. Soc. Jpn., 2012, 85, 1203; (k) M. Shimizu, D. Kurita and I. Mizota, Asian J. Org. Chem., 2013, 2, 208; (l) T. Sano, I. Mizota and M. Shimizu, Chem. Lett., 2013, 42, 995; (m) I. Mizota, Y. Matsuda, S. Kamimura, H. Tanaka and M. Shimizu, Org. Lett., 2013, 15, 4206; (n) H. Tanaka, I. Mizota and M. Shimizu, Org. Lett., 2014, 16, 2276; (o) K. Koyama, I. Mizota and M. Shimizu, Pure Appl. Chem., 2014, 86, 755; (p) M. Shimizu, M. Tateishi and I. Mizota, Chem. Lett., 2014, 43, 1752; (q) I. Mizota, T. Maeda and M. Shimizu, Tetrahedron, 2015, 71, 5793; (r) I. Mizota and M. Shimizu, Chem. Rec., 2016, 16, 688; $(s)$ T. Tanaka, I. Mizota, K. Umezu, A. Ito and M. Shimizu, Heterocycles, 2017, 95, 830; $(t)$ M. Kawanishi, I. Mizota, K. Aratake, H. Tanaka, K. Nakahama and M. Shimizu, Bull. Chem. Soc. Jpn., 2017, 90, 395; (u) I. Mizota, Y. Nakajima, A. Higashino and M. Shimizu, Arabian J. Sci. Eng., 2017, 42, 4249; (v) I. Mizota, C. Ueda, Y. Tesong, Y. Tsujimoto and M. Shimizu, Org. Lett., 2018, 20, 2291; (w) K. Nakahama, M. Suzuki, M. Ozako, I. Mizota and M. Shimizu, Asian J. Org. Chem., 2018, 7, 910.

6 M. Shimizu, Y. Takao, H. Katsurayama and I. Mizota, Asian J. Org. Chem., 2013, 2, 130.

7 (a) L. Blackburn and R. J. K. Taylor, Org. Lett., 2001, 3, 1637; (b) T. Mukaiyama, A. Kawana, Y. Fukuda and J. Matsuo, Chem. Lett., 2001, 390; (c) K. C. Nicolaou, C. J. N. Mathison and T. Montagnon, Angew. Chem., 2003, 115, 4211; (d) M. S. Kwon, S. Kim, S. Park, W. Bosco, R. K. Chidrala and J. Park, J. Org. Chem., 2009, 74, 2877; (e) E. Zhang, H. Tian, S. Xu, X. Yu and Q. Xu, Org. Lett., 2013, 15, 2704; $(f)$ R. Kumar, E. H. Gleißner, E. G. V. Tiu and Y. Yamakoshi, Org. Lett., 2016, 18, 184.
8 For the formation of hemiaminal ethers, see, (a) G. Li, F. R. Fronczek and J. C. Antilla, J. Am. Chem. Soc., 2008, 130, 12216; (b) K. Xu, Z. Wang, J. Zhang, L. Yu and J. Tan, Org. Lett., 2015, 17, 4476; (c) A. Beltran, E. Alvarez, M. M. Diaz-Requejo and P. J. Pereza, Adv. Synth. Catal., 2015, 357, 2821; (d) M. Li, B. Luo, Q. Liu, Y. Hu, A. Ganesan, P. Huang and S. Wen, Org. Lett., 2014, 16, 10; (e) H. Yu and J. Shen, Org. Lett., 2014, 16, 3204; (f) For a related work, see, T. Kano, T. Yurino, D. Asakawa and K. Maruoka, Angew. Chem., Int. Ed., 2013, 52, 5532.

9 (a) M. A. Avery, W. K. M. Chong and C. Jennings-White, J. Am. Chem. Soc., 1992, 114, 974; (b) L. Rçsch, G. Altnau and W. H. Otto, Angew. Chem., Int. Ed., 1981, 20, 581.

10 (a) A. G. Brook and J. M. Duff, J. Am. Chem. Soc., 1974, 96, 4692; (b) T. Honda and M. Mori, J. Org. Chem., 1996, 61, 1196; (c) M. Suginome, T. Fukuda and Y. Ito, J. Organomet. Chem., 2002, 643, 508.

11 For the bromination of silyl enol ethers, see, $(a)$ R. H. Reuss and A. Hassner, J. Org. Chem., 1974, 39, 1785; (b) L. Blanco, P. Amice and J. M. Conia, Synthesis, 1976, 194; (c) G. F. Hambly and T. H. Chan, Tetrahedron Lett., 1986, 27, 2563.

12 For the oxidative formation of iminium salts from amino ketene silyl acetals, see, S. Hata, H. Koyama and M. Shimizu, J. Org. Chem., 2011, 76, 9670.

13 (a) J. L. Luche and A. L. Gemal, J. Am. Chem. Soc., 1979, 101, 5848; (b) M. T. Reetz, B. Wenderoth and R. Peter, J. Chem. Soc., Chem. Commun., 1983, 406; (c) K. Maruoka, S. Saito, A. B. Concepcion and H. Yamamoto, J. Am. Chem. Soc., 1993, 115, 1183; (d) G. Bastug, S. Dierick, F. Lebreux and I. E. Mark, Org. Lett., 2012, 14, 1306; (e) H. Fujioka, K. Yahata, O. Kubo, Y. Sawama, T. Hamada and T. Maegawa, Angew. Chem., Int. Ed., 2011, 50, 12232; $(f)$ F. J. Barrios, B. C. Springer and D. A. Colby, Org. Lett., 2013, 15, 3082 .

14 Although we attempted to synthesize $N, O$-bis-TBS derivative of the compound $\mathbf{1 2}$ or its TIPS counterpart as a trialkylsilylprotected derivative, upon treatment with an excess TBS-Cl, only the mono-O-TBS derivative $\mathbf{1 4}$ was isolated after workup, whereas an excess TIPS-Cl treatment led to the recovery of the starting material 12 .

15 (a) P. Imming, I. Imhof and M. Zentgraf, Synth. Commun., 2001, 31, 3721; (b) B. D. Allison, V. K. Phuong, L. C. McAtee, M. Rosen, M. Morton, C. Prendergast, T. Barrett, G. Lagaud, J. Freedman, L. Li, X. Wu, H. Venkatesan, M. Pippel, C. Woods, M. C. Rizzolio, M. Hack, K. Hoey, X. Deng, C. King, N. P. Shankley and M. H. Rabinowitz, J. Med. Chem., 2006, 49, 6371. 